\title{
ALTERNATE IMMERSION STRESS CORROSION TESTING OF 5083 ALUMINUM
}

John L. Briggs

Marston R. Dringman

Chemistry Research and Development

COMPONENT DEVELOPMENT

David E. Hausburg

Chemistry Research and Development INSTRUMENTATION AND STATISTICAL SYSTEMS

Ross J. Jackson

Product Research and Development PHYSICAL METALLURGY GROUP

\section{SUBJECT DESCRIPTORS}

Stress Corrosion Aluminum Alloys Instrumentation

\section{ROCKWELL INTERNATIONAL ENERGY SYSTEMS GROUP ROCKY FLATS PLANT P.O. BOX 464 GOLDEN, COLORADO 80401}

Prepared under Contract DE-AC04-76DPO3533 for the Albuquerque Operations Office U.S. Department of Energy
This neport wis moTICE

ans report was prepared as an eccount of work United States nor the Unitas Government. Neither the Energy, nor any of their ented States Department of contractors, subcontractir employees, nor any of their iny warranty, oxpreser or in or their employees, makes liability or respies or inglied, or asturnes any legal a unefulnes of any for the accuracy, completeness process dieclomed thormation, apparatus, product or infringe privately, or hepresents that its ue would not 


\section{DISCLAIMER}

This report was prepared as an account of work sponsored by an agency of the United States Government. Neither the United States Government nor any agency Thereof, nor any of their employees, makes any warranty, express or implied, or assumes any legal liability or responsibility for the accuracy, completeness, or usefulness of any information, apparatus, product, or process disclosed, or represents that its use would not infringe privately owned rights. Reference herein to any specific commercial product, process, or service by trade name, trademark, manufacturer, or otherwise does not necessarily constitute or imply its endorsement, recommendation, or favoring by the United States Government or any agency thereof. The views and opinions of authors expressed herein do not necessarily state or reflect those of the United States Government or any agency thereof. 


\section{DISCLAIMER}

Portions of this document may be illegible in electronic image products. Images are produced from the best available original document. 


\section{CONTENTS}

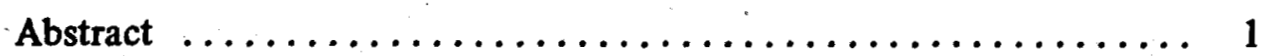

Introduction $\quad \ldots \ldots \ldots \ldots \ldots \ldots \ldots \ldots \ldots \ldots \ldots \ldots \ldots \ldots$

Test Equipment Design and Construction $\ldots \ldots \ldots \ldots \ldots \ldots \ldots$

Experimental Procedure $\ldots \ldots \ldots \ldots \ldots \ldots \ldots \ldots \ldots \ldots$

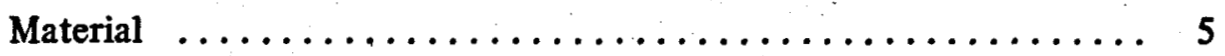

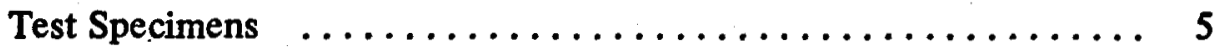

Specimen Preparation $\ldots \ldots \ldots \ldots \ldots \ldots \ldots \ldots \ldots \ldots \ldots, 5$

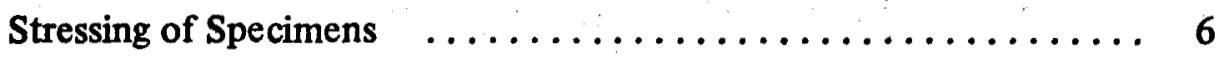

Test Medium $\ldots \ldots \ldots \ldots \ldots \ldots \ldots \ldots \ldots \ldots \ldots \ldots \ldots \ldots \ldots \ldots \ldots$

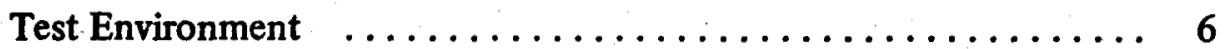

Examination for Cracks $\ldots \ldots \ldots \ldots \ldots \ldots \ldots \ldots \ldots$

Corrosion Cracking of Aluminum-Magnesium Alloys _........... 8

Aluminum-Magnesium Alloys $\ldots \ldots \ldots \ldots \ldots \ldots \ldots \ldots \ldots, 8$

Intercrystalline Corrosion $\ldots \ldots \ldots \ldots \ldots \ldots \ldots \ldots \ldots$

Stress Corrosion $\ldots \ldots \ldots \ldots \ldots \ldots \ldots \ldots \ldots \ldots \ldots$

Results of Alternate Immersion Tests ............... 9

Test on As-Received 5083 H321 Plate $\ldots \ldots \ldots \ldots \ldots \ldots . \ldots 9$

Tests on Annealed and Cold-Rolled Plate . ............ 9

Tests for Various Experimental

Heat Treatments and Forming Parameters $\ldots \ldots \ldots \ldots \ldots \ldots$

Acceptance Tests for Two Fabrication Procedures .......... 10

Acceptance Tests for

an Alternate Fabrication Procedure $\ldots \ldots \ldots \ldots \ldots \ldots \ldots \ldots$

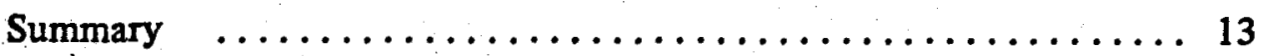

References $\ldots \ldots \ldots \ldots \ldots \ldots \ldots \ldots \ldots \ldots \ldots \ldots \ldots \ldots \ldots$ 
RFP-2645 


\section{ACKNOWLEDGMENTS}

A sincere acknowledgment is extended to J. L. Blakeslee and C. M. Edstrom for directing the fabrication aspects of the study and for their assistance in planning the overall study. 
RFP-2645 


\title{
ALTERNATE IMMERSION STRESS CORROSION TESTING OF
}

5083 ALUMINUM

\author{
John L. Briggs, Marston R. Dringman, David E. Hausburg,
} and Ross J. Jackson

\begin{abstract}
The stress corrosion susceptibility of Type 5083 aluminum-magnesium alloy in plate form and press-formed shapes was determined in the short transverse direction. C-ring type specimens were exposed to alternate immersion in a sodium chloride solution. The test equipment and procedure, with several innovative features, are described in detail. Statistical test results are listed for seven thermomechanical conditions. A certain processing scheme was shown to yield a work-strengthened part that is not sensitized with respect to stress corrosion cracking.
\end{abstract}

\section{INTRODUCTION}

During the past 20 years, wrought aluminum alloys containing 4 to $5.5 \mathrm{wt} \%$ magnesium have become readily available on a commercial basis in the United States. These alloys were foreshadowed in their appearance here by widespread usage in Great Britain and Europe. In addition to having a high degree of corrosion resistance, these alloys are easily welded and possess good mechanical properties. This combination of factors places them in a position to compete with steels and other aluminum alloys in many structural applications.

In the literature, there are reports about the possibility of stress corrosion cracking (SCC) with these alloys when they are cold-worked. The cracking results either from exposure to temperatures in the range of 65 to $205^{\circ} \mathrm{C}$, or from aging at room temperature for many years. 2 conventional method for this testing is to expose suitably prepared specimens to alternate immersion. This is done in an aqueous $3.5 \mathrm{wt} \%$ sodium chloride solution while the specimens are stressed to $75 \%$ of their yield strength. ${ }^{1}$ The standard recommended practice for alternate immersion stress corrosion testing has been designated in ASTM G44-75. ${ }^{3}$ Among the alloys just described is one known as 5083 , which is the subject of this report.

\section{TEST EQUIPMENT DESIGN AND CONSTRUCTION}

An alternate immersion test system with several innovative features was designed and built for this study. The fluid flow, valving, and certain electrical controllers are shown schematically in Figure 1. A back view of the test system is shown photographically in Figure 2. Test samples (stressed C-rings of 5083 aluminum) are placed on Teflon racks in the specimen immersion tank until the SCC test samples are completely immersed. The samples remain immersed in the test solution for a timed interval (10 minutes). At the conclusion of the timed interval, the solution is drained from the immersion tank into the supply tank and the sample drying time interval begins. At the conclusion of the drying time interval (50 minutes), the alternate immersion-drying cycle is repeated. The test apparatus continues to cycle through the immersion-drying functions until the test is terminated ( 30 days).

The ASTM standard recommended practice for alternate immersion suggests various methods to accomplish this. ${ }^{3}$ The open tank method was investigated and was considered to be the most practical. In the open tank method, alternate 


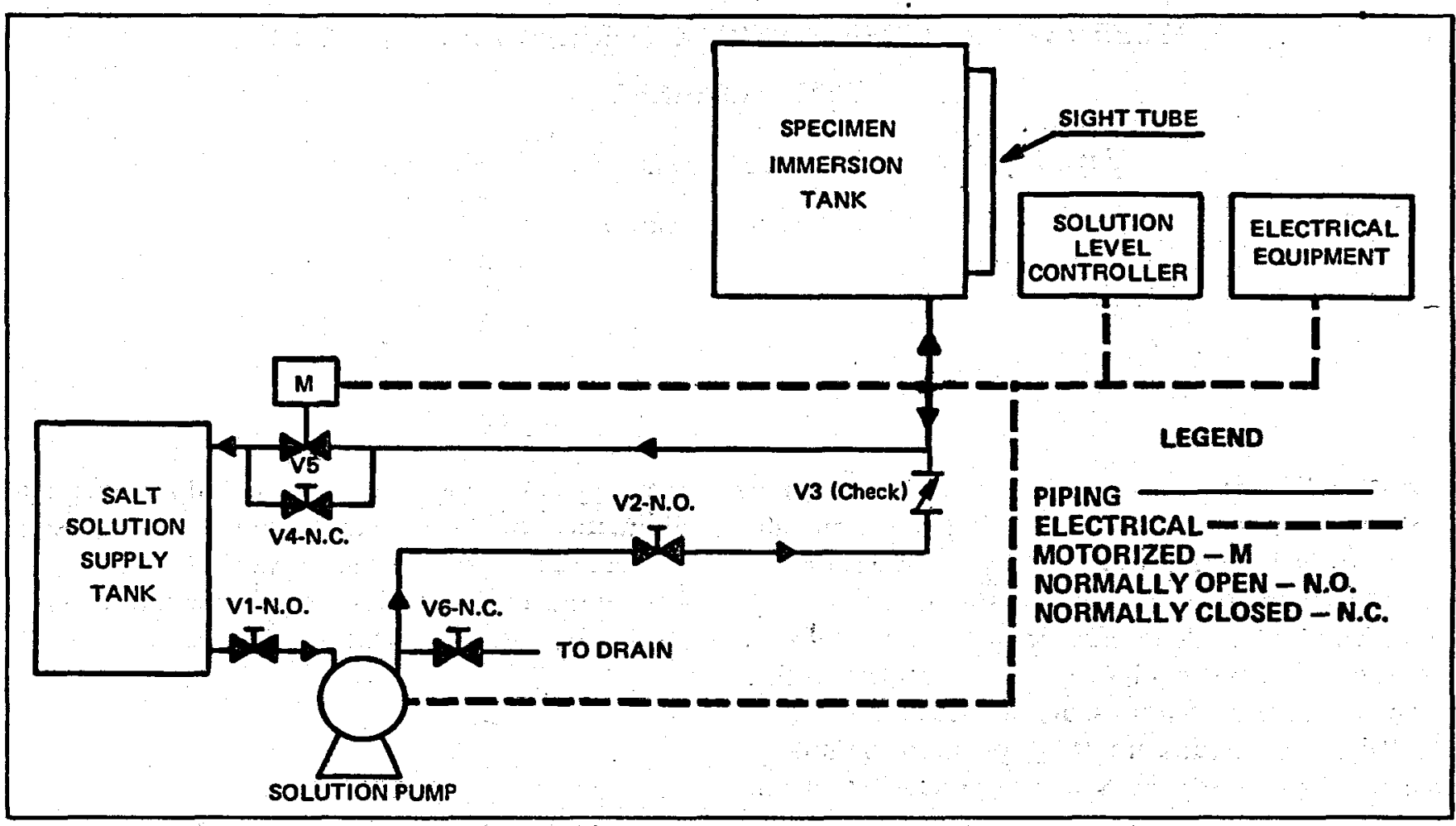

FIGURE 1. Alternate Immersion Stress Corrosion Test System Showing Fluid Flow Routes, Valving, and Certain Electrical Controllers

immersion is accomplished by transferring solution from a supply tank into an immersion tank. Pneumatic or electric motor pump transfer are two means used for transferring solution. Availability of electric power was the factor in selecting the pump transfer method over the pneumatic transfer method. Because of the corrosive nature of the test solution, all wetted parts of the system were assembled with chemically inert polymer components.

The immersion tank size was established by the projected quantity and size of test samples. A standard $18 \times 18 \times 12$ in. polypropylene vessel was selected for the immersion tank. To provide adequate solution for immersion; a polypropylene tank of the same dimension was selected for the supply tank. Immersion tank volume at the required level and the maximum time prescribed for immersion of a specimen were the factors used in selecting the solution pump size. A table showing flow rate data for chemical pumps was used for the selection of the solution pump. All pump parts in contact with the solution are of molded Ryton plastic.

Selection of the tank drain valve size was based on immersion tank drain time and the tank volume at the specimen immersion level. A nomogram of standard pipe size, flow velocity, and flow rate was used to select the drain valve size. ${ }^{4}$ Wetted valve parts, pipe connections, and pipelines are all polyvinyl chloride polymers.

Transparent tubing attached to the side of the immersion tank provides a means for observing the solution level in the tank. The tubing is Tygon, which is a chemically inert polymer. A light emitting diode (LED) sensor that responds to the solution level was attached to the Tygon tubing. 


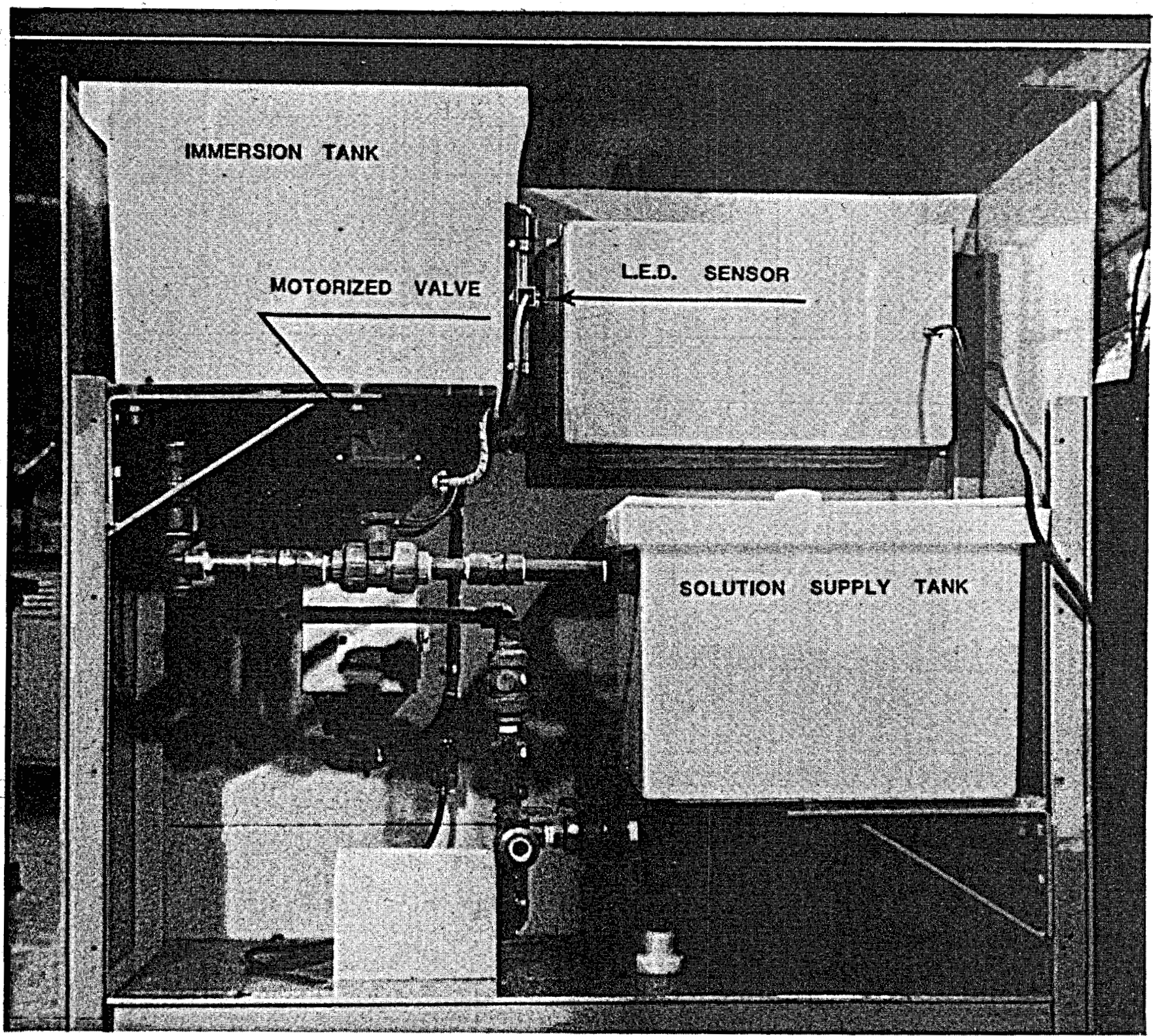

FIGURE 2. Back View of Altemate Immersion Stress Corrosion Test System

The sensor, along with associated electronics, provides the means for controlling solution level in the immersion tank. The sensor position can be adjusted up or down.

An electrical schematic for the altemate immersion stress corrosion test system is shown in Figure 3. Initial application of power to the electrical circuits causes the motor-driven valve, V5, to drive to the closed position (Figure 1). Actuation of the "pump start" push button on the control panel starts the pump; and solution transfer begins. The flow of solution is through pipelines (Figures 1 and 2) from the supply tank into the immersion tank.

The position of the LED sensor, which is attached to the sight tube, establishes the solution level in the immersion tank. Solution being transferred to the tank rises in the sight tube until the LED light beam is interrupted. At this time, two electricalmechanical actions occur: the solution pump stops, which terminates solution transfer; simultaneously 


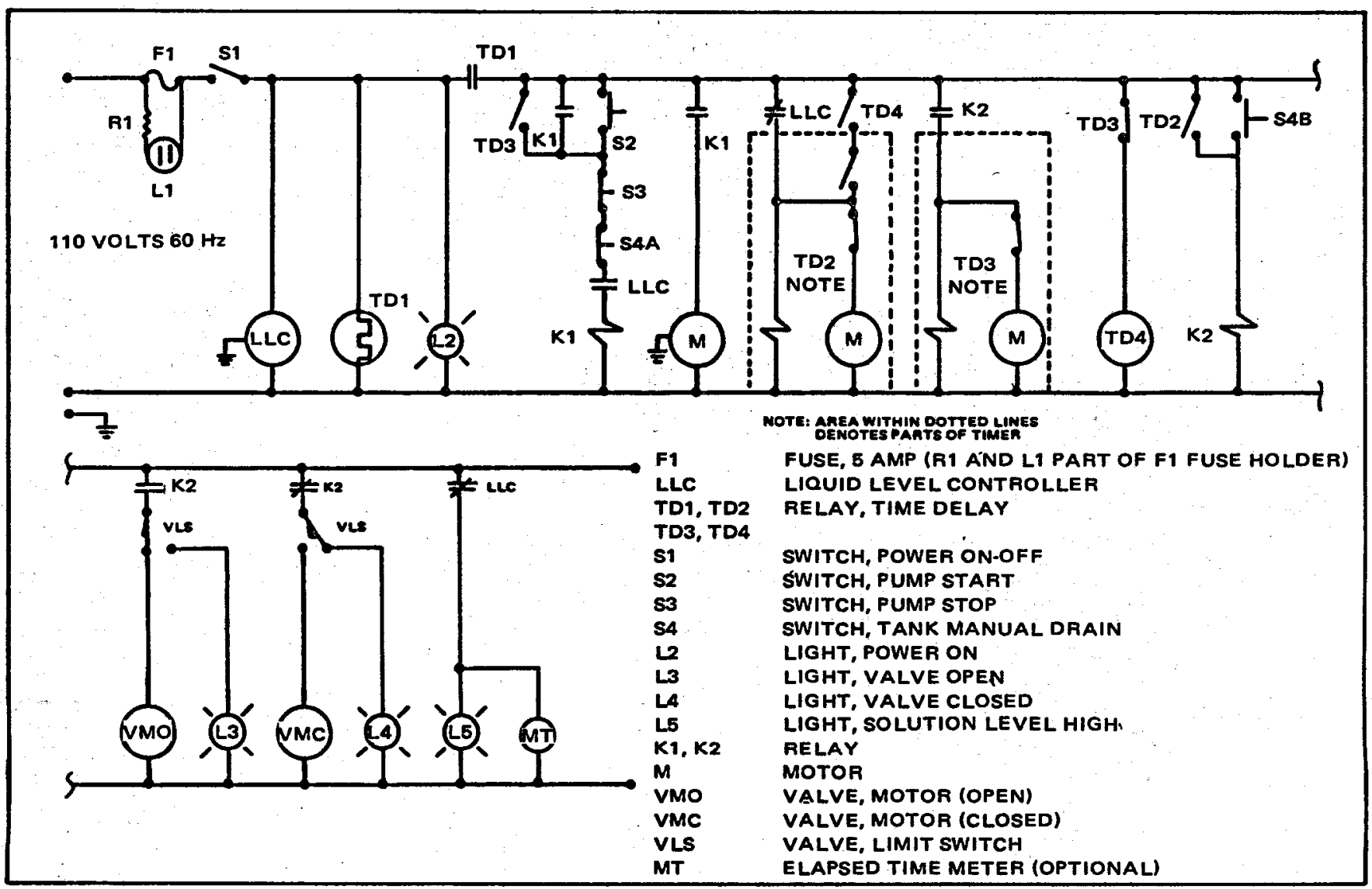

FIGURE 3. Electrical Schematic of the Alternate Immersion Stress Corrosion Test System

the immersion timer starts and thus the immersion time interval begins. Check Valve V3 (Figure 1) prevents solution from draining from the immersion tank through the pump into the supply tank during the immersion time interval.

Valve V5 drives to the open position at the conclusion of the immersion time interval. This action is caused by the immersion timer. Gravity flow empties the immersion tank through Valve V5 inte the supply tank. Simultaneous to Valve V5 driving to the open position, the drying timer starts and thus the drying time interval begins. At the conclusion of the drying time interval, both the drying timer and the immersion timer reset to zero. This reset action causes Valve V5 to drive to the closed position; the action also restarts the solution pump. In this manner, the apparatus continues to cycle through the specimen immersion-drying operations until the test is manually terminated. Two means are provided to stop the automatic cycle. Actuation of either the manual tank drain push button or the power on-off push button electrically interrupts the cyclic action, and the immersion drying operations are terminated.

Maximum fill time for the immersion tank was designed to be less than 2.0 minutes. In practice, the average immersion time is 1.7 minutes. Solution drain time from the immersion tank was prescribed to be less than 2.0 minutes, but average stop watch checks indicate an actual drain time of 1.8 minutes.

The alternate immersion stress corrosion test system has operated on a continuous basis for nearly two years with the exception of shutdowns for specimen changing. No plumbing or electrical malfunctions have occurred in this period, and the system is continuing to operate satisfactorily. 


\section{EXPERIMENTAL PROCEDURE}

Material

Material consisted of 1-in.- and 0.75-in.-thick plate of 5083 aluminum purchased in the H321 temper designation in the as-received, solution-quenched, and press-formed condition. The $\mathrm{H}$ indicates a strain hardened alloy; $\mathrm{H} 3$ shows the alloy to be cold worked and then stabilized by a low temperature anneal to prevent age-softening at room temperature; $\mathrm{H} 32$ indicates a quarter hard temper for the degree of strain hardening in the finished product; the third digit indicates a variation in production method or degree of control of properties. Chemical composition of the 5083 alloy used in this study is listed in Table 1.

\section{Test Specimens}

Short transverse, C-ring type specimens were machined from the plate so that the centerline of the specimen, which is the area of maximum applied stress, represents the centerline of the plate. Figure 4 shows the specimen orientation in relation to the plate rolling direction. Other $\mathrm{C}$-rings were obtained from press-formed plate as shown in Figure 5.

Three sizes of C-ring specimens were used: 0.750 , 0.700 -, and 0.500 -in. 0 . d. with wall thicknesses of $0.060,0.056$, and $0.040 \mathrm{in}$. respectively. Normally the 0.750 -in. rings were from 1 -in.-thick plate, the 0.700-in. rings from 0.750 -in.-thick plate, and the 0.500 -in. rings from pressed shapes. All rings were 0.750 in. in width. Figure 6 shows the geometry and dimensions of the test specimens.

\section{Specimen Preparation}

The C-ring specimens were degreased with a 2 vol $\%$ aqueous detergent cleaner (a mild liquid detergent composed of alkali orthophosphates, alkali xylene sulfonate, and alkylphenol polyoxyethylene condensate) in distilled water at room temperature and with sonication. This step lasted 5 minutes. The specimens were then rinsed for 5 minutes in flowing, cascading, distilled water before being air
TABLE 1. Chemical Analysis of 5083 Aluminum Alloy

\begin{tabular}{|c|c|c|}
\hline Element & $\begin{array}{l}\text { Rocky Flats } \\
\text { Chemical Analysis } \\
\text { Measurements* }\end{array}$ & $\begin{array}{l}\text { Manufacturer's } \\
\text { Chemical Analysis } \\
\text { Limits }\end{array}$ \\
\hline $\mathbf{M g}$ & $4.1-4.8$ wt $\%$ & $4.0-4.9$ wt $\%$ \\
\hline $\mathbf{M n}$ & $0.88-0.89$ & $0.30-1.0$ \\
\hline $\mathbf{C r}$ & $0.09-0.14$ & $0.05-0.25$ \\
\hline $\mathrm{Fe}$ & $0.25 \cdot 0.28$ & $0.40 \max$ \\
\hline Si & $0.13-0.14$ & $0.40 \max$ \\
\hline $\mathrm{Zn}$ & $0.04-0.09$ & $0.25 \max$ \\
\hline $\mathbf{T i}$ & $0.02-0.04$ & $0.15 \max$ \\
\hline $\mathbf{C u}$ & $0.02-0.04$ & $0.10 \max$ \\
\hline $\mathrm{H}_{2}$ & $6 \cdot 10 \mathrm{ppm}$ & - \\
\hline
\end{tabular}

*Range of values from two heats of Alcoa sheet and one heat of Kaiser sheet.

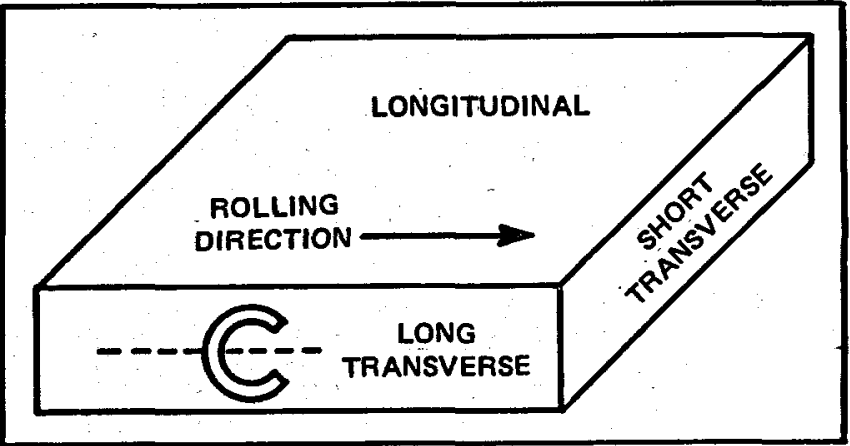

FIGURE 4. Orientation of C-Ring in Relation to Plate

FIGURE 5. Orientation of C-Rings in Relation to Press-Formed Plate

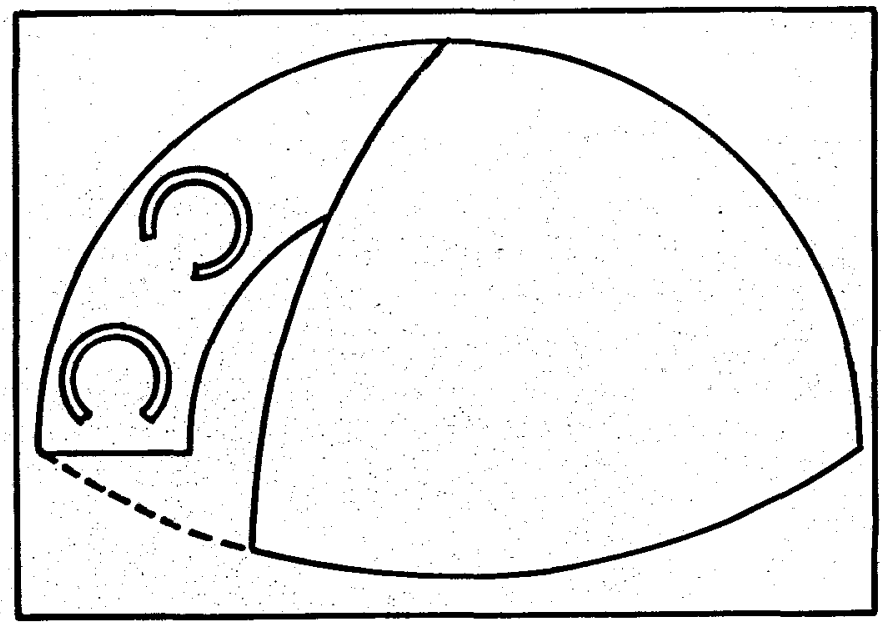




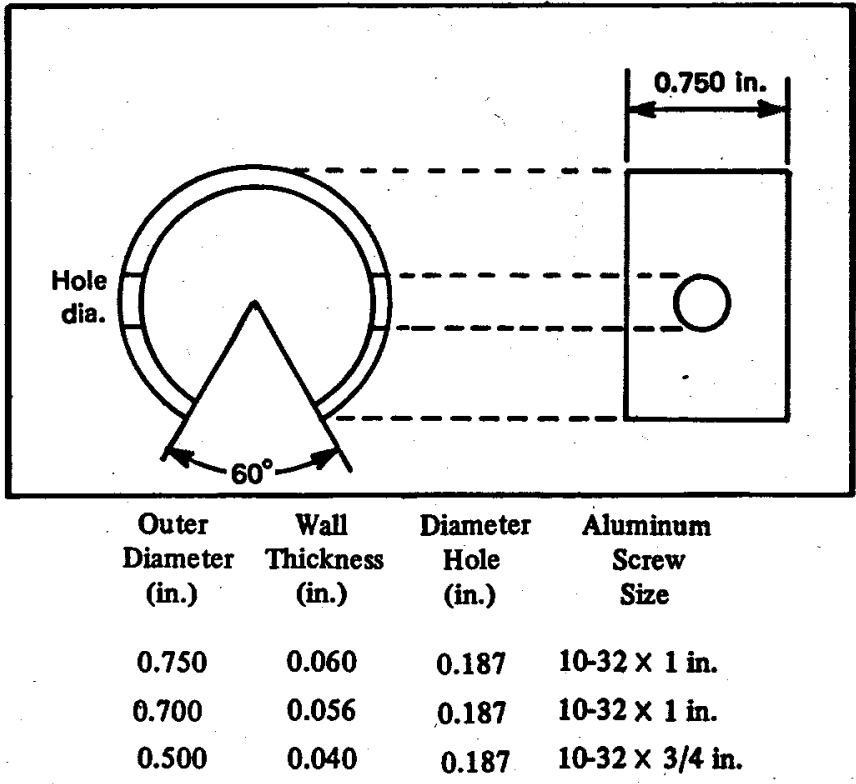

FIGURE 6. Dimensions of C-Ring Specimens

dried for one hour. After the specimens were stressed, the above procedure was repeated. The samples were then remeasured with a hand micrometer to ensure that no loosening of the nut-bolt (i.e., loss of stress) had occurred.

Aluminum nuts and bolts were used to stress the C-ring specimens. To avoid galvanic effects between the aluminum nuts and bolts and the 5083 aluminum C-rings, specimens were coated in the sensitive areas. The coating consisted of two dips in Turco 5580G (acrylonitrile butadiene styrene terpolymer) followed by one dip in polyurethane. No deterioration of the coating was observed after 30 days of alternate immersion in the $3.5 \mathrm{wt} \%$ sodium chloride solution. A coated C-ring specimen is shown in Figure 7.

\section{Stressing of Specimens}

C-ring specimens were stressed by tightening a screw and nut to reduce the ring diameter. The following formula was used to determine the desired stress in terms of specimen properties and dimensions.

where

$$
\Delta=\frac{\mathrm{f} \pi \mathrm{D}^{2}}{4 \mathrm{EtZ}}
$$

$$
\begin{aligned}
& \Delta= \text { Change of outside diameter required for } \\
& \text { desired stress }
\end{aligned}
$$

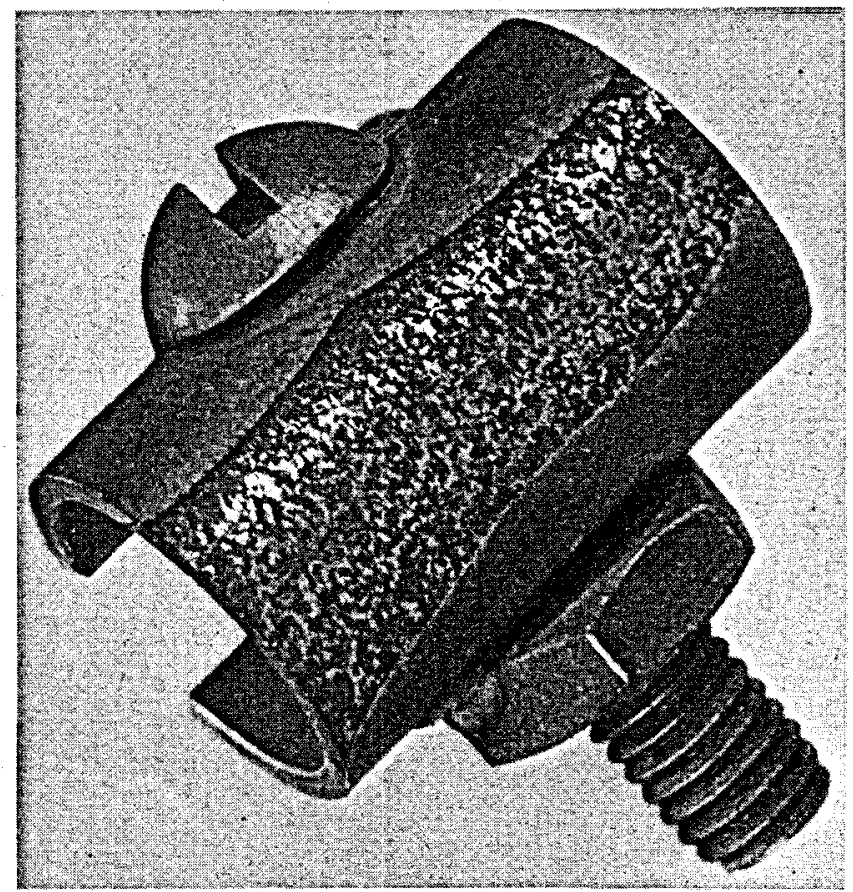

$24060-8$

FIGURE 7. Coated C-Ring Sample

$$
\begin{aligned}
\mathbf{f}= & \text { desired stress }(\mathrm{psi}) \\
\mathbf{t}= & \text { wall thickness }(\mathrm{in} .) \\
D= & \text { mean diameter in inches }(0 . d .-t) \\
E= & \text { modulus of elasticity }(\mathrm{psi}) \\
Z= & \text { a constant (function of ring } D / t \\
& \text { see Reference } 3 \text { ). }
\end{aligned}
$$

\section{Test Medium}

The test solution was 3.5 wt \% reagent grade sodium chloride and distilled water prepared bi-weekly. Salinity of the solution was checked periodically with a hydrometer, and distilled water was added to compensate for any evaporation. No attempt was made to control $\mathrm{pH}$, which was 7.0 when the solution was made and 7.3 to 7.4 when the solution was discarded after two weeks of use.

\section{Test Environment}

The alternate immersion test system was in a separate room in which temperature and humidity were closely controlled. 


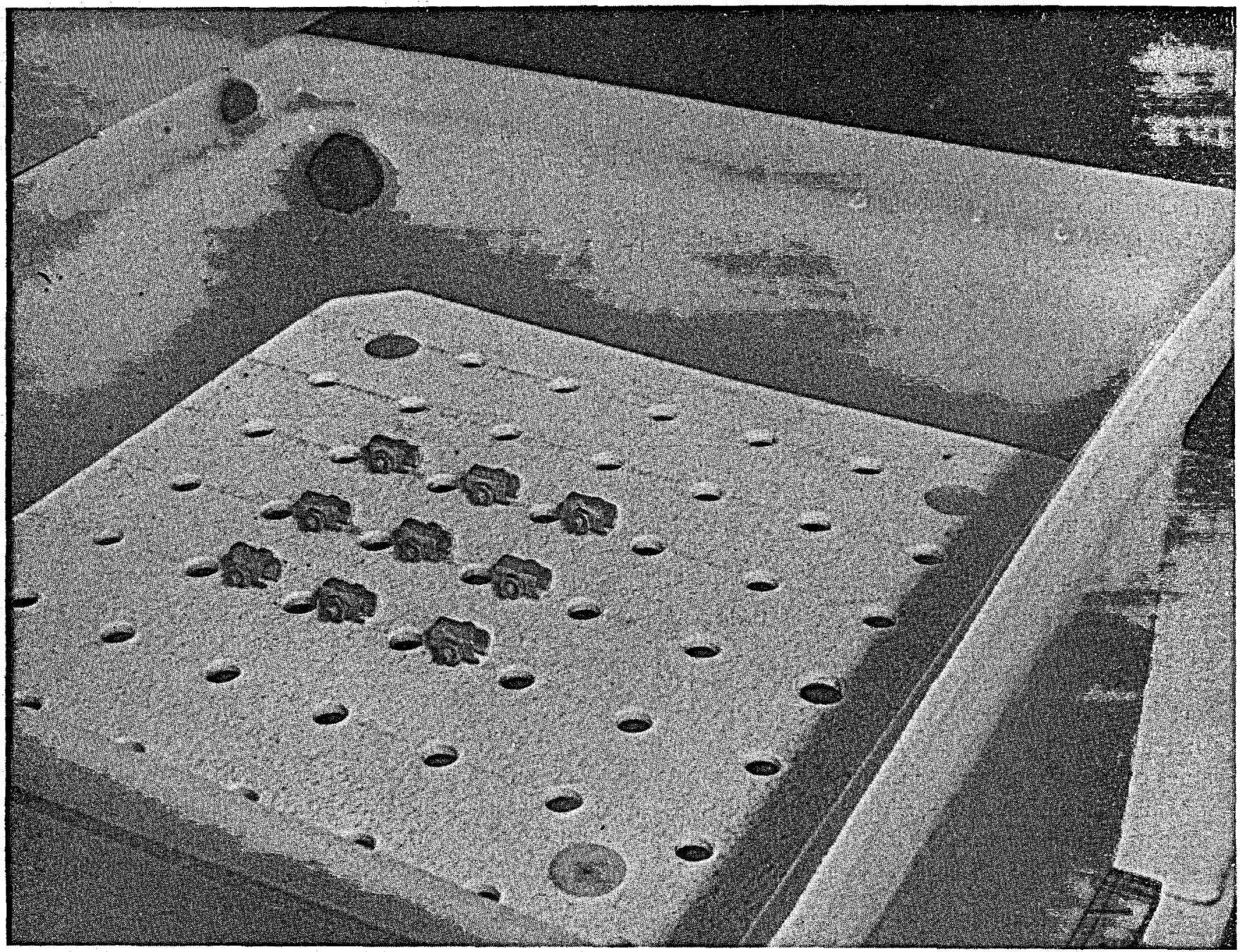

FIGURE 8. A set of C-Rings in the Test Specimen Immersion Tank

Humidity was held at $45 \pm 5 \%$ relative humidity and was monitored continuously, Temperature was held at $26.7^{\circ} \mathrm{C}$ and also was monitored continuously. Rosenthal and Pritchard's data showed that constant temperature and relative humidity must be maintained in the alternate-immersion test to obtain significant and reproducible results. 5 . The ASTM procedure for alternate immersion testing specifies $26.7^{\circ} \mathrm{C}$ and $45 \%$ relative humidity. ${ }^{3}$

\section{Examination for Cracks}

The presence of cracks was determined by visual inspection with the aid of a $10 \mathrm{X}$ magnifier. Special attention was paid to the edges of the $\mathrm{C}$-rings where cracks would be expected. If there was doubt as to whether a crack had nucleated or whether there was merely pitting attack, the area was noted. Subsequent examinations then were directed to this area of the specimen to see if a crack had occurred.

Alternate immersion tests were kept under observation except over weekends. The observation period on weekdays was between the working hours of 7:30 a.m. and 4:00 p.m. The number of examinations carried out daily varied from one to two. A set of C-rings in the test specimen tank is shown in Figure 8. 
CORROSION CRACKING OF

\section{ALUMINUM-MAGNESIUM ALLOYS}

\section{Aluminum-Magnesium Alloys}

A phase diagram of the aluminum-magnesium system is shown in Figure 9.6 The range of solid solution is large $\left(15 \%\right.$ at $\left.450^{\circ} \mathrm{C}\right)$, and alloys up to $7 \%$ magnesium are used in the wrought condition. In the annealed condition the increase in tensile strength is proportional to magnesium content, about $16 \mathrm{ksi}$ at $1 \% \mathrm{Mg}, 28 \mathrm{ksi}$ at $3 \% \mathrm{Mg}$, and $36 \mathrm{ksi}$ at $5 \% \mathrm{Mg}$, while the ductility as measured by elongation in the tensile test remains high. These alloys work-harden rapidly, and the higher the magnesium content, the more rapidly they work-harden.

Magnesium alloys are readily welded by the argon arc process, using either a tungsten electrode and appropriate filler rod [tungsten inert gas (TIG) process] or a consumable metal electrode [metal inert gas (MIG) process]. Both processes give joint efficiencies of 80 to $90 \%$ in relation to the strength values of the parent metal in the soft condition. For this reason, these processes are used for the fabrication of engineering structures and pressure vessels.

In general, the corrosion resistance of these alloys is high, particularly in marine environments. In alloys with higher magnesium content, there is a tendency for the $\beta$-phase $\left(\mathrm{Mg}_{2} \mathrm{Al}_{3}\right)$ to precipitate along the crystal or grain boundaries and lead to some susceptibility to stress corrosion. This tendency is caused by the diminished solubility of magnesium at low temperatures.

The precipitation is extremely slow at room temperature, but more rapid at $70-100^{\circ} \mathrm{C}$. It is therefore inadvisable to use alloys with over $3 \%$ magnesium for high temperature service in corrosive environments.

Small quantities of maganese or chromium are added to aluminum-magnesium alloys to raise the recrystallization temperature and increase the strength for a given magnesium content. The 5083 alloy contains $4.0-4.9 \%$ magnesium, $0.30-1.0 \%$ manganese, and $0.05-0.25 \%$ chromium. The mag-

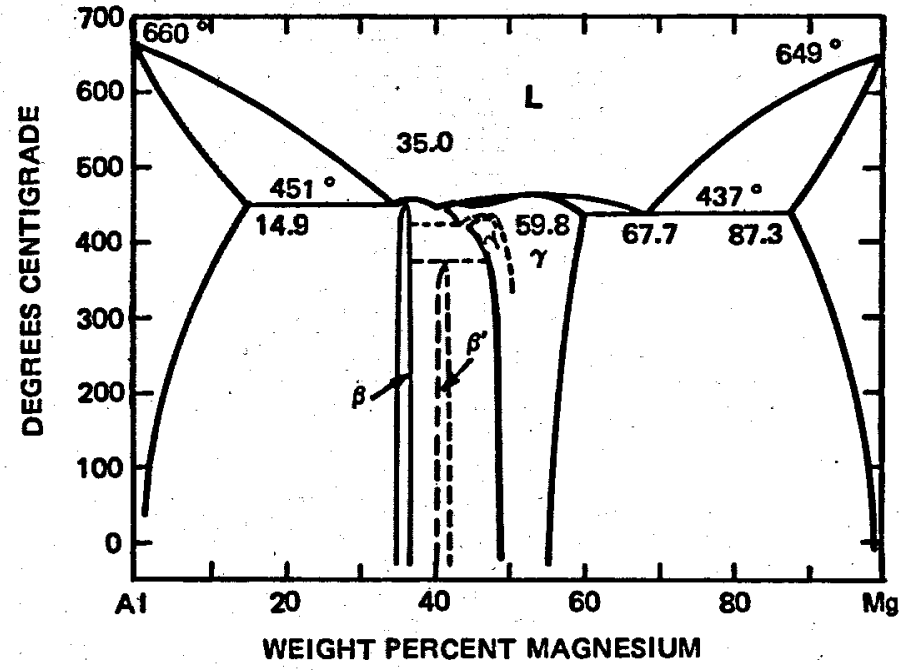

NOTE: This figure is from "Metallographic Structures and Phase Diagrams," Metals Handbook 8:261. American Society for Metalls, Metals Park, Ohio. 1973.

FIGURE 9. Aluminum-Magnesium Phase Diagram

nesium content is not low enough to avoid stress corrosion due to precipitation of the $\beta$-phase; however, the added manganese and chromium give it the tensile strength of a higher magnesium alloy that would be more susceptible to stress corrosion:

In the cold-worked condition, these alloys exhibit a phenomenon known as age-softening. Over a period of time, tensile strength and yield strength of the cold-worked alloy decrease rapidly at first and then more slowly. After a few months, the rate of change is so slow it is barely detectable, but over a period of a year, the total drop in tensile strength may be as much as $2 \mathrm{ksi}$. For this reason, the alloys are often marketed in the $\mathrm{H} 3$ tempers, which are cold-worked to a level slightly higher than desired and then stabilized by heating to a temperature of 120 to $150^{\circ} \mathrm{C}$. This lowers the properties to a desired level and stabilizes them with respect to time.

\section{Intercrystalline Corrosion}

In the $\mathbf{5 0 8 3}$ alloy, it is possible for the grain boundary regions to become anodic with respect 
to the interior of the crystal and therefore to corrode preferentially. The magnesium normally is in solid solution, and if precipitation of the $\beta$-phase $\left(\mathrm{Mg}_{2} \mathrm{Al}_{3}\right)$ occurs, it generally is distributed and causes little harm. Under certain conditions, notably prolonged exposure of the work-hardened tempers to tropical temperatures, continuous grain boundary precipitation of the $\beta$-phase can take place. This precipitate is itself anodic with respect to the rest of the alloy, and is therefore attacked preferentially, under adverse conditions, which gives rise to severe intercrystalline corrosion.

\section{Stress Corrosion}

Stress corrosion may be defined as the rapid propagation of cracks under the combined influence of corrosion and tensile stress. In aluminum alloys, cracks are typically intercrystalline, and susceptibility to intercrystalline corrosion is a prerequisite. The process in aluminum alloys involves three stages:

1. The formation of a notch by the normal slow process of intercrystalline corrosion.

2. Local plastic deformation at the root of the notch, which may start a crack. In any case, this deformation disrupts any protective film and exposes fresh metal to corrosion.

3. Rapid attack of the exposed metal leading to the reformation of a surface film and the resumption of normal intercrystalline attack.

The rate of attack depends greatly upon the magnitude of the applied stress and upon direction of the stress in relation to the metallurgical structure. Thus, with extrusions that often have a fibrous structure, a longitudinal stress is far less serious than a transverse stress. Furthermore, except with a highly stressed structure, the application of normal safety factors results in design stresses low enough that serious trouble with stress corrosion is avoided. Unfortunately, built-in stresses due to welding, interference fits of pins and bushes, and the bolting together of imperfectly matching components can reach a level close to the yield stress of the material. For this reason, stress corrosion tests are normally carried out at a fixed proportion ( 75 or $90 \%$ ) of the yield stress.
In aluminum-magnesium alloys, precipitation of the $\beta$-phase along grain boundaries to form a continuous film results in susceptibility to stress corrosion. This is most commonly encountered in alloys containing over $3 \%$ magnesium that have been coldworked to increase the strength, and then exposed for prolonged periods to a tropical environment. Marked susceptibility is found mainly in the short transverse direction of thick plate.

\section{RESULTS OF ALTERNATE IMMERSION TESTS}

The primary objective of this study was to provide stress corrosion cracking (SCC) testing support for the fabrication of a high-strength, non-sensitized pressing from 5083 aluminum sheet. The results are presented roughly in chronological order and traces the development work to fabricate a part that was not subject to stress corrosion cracking.

\section{Tests on As-Received 5083-H321 Plate}

The first experimental series of alternate immersion SCC tests was performed on four sets of C-rings fabricated from as-received 5083-H321 plate. Results of these SCC tests are listed in Table 2. Sample Sets 1 and 2 were from one-inch-thick plate (0.75-in.-o. d. C-rings) while sample sets 3 and 4 were from 0.75 -in-thick plate (0.70-in,-o. d. C-rings).

Sample Sets 1,2, and 4 failed the ASTM alternate immersion SCC test specification that no more than two specimens (from a sample population of nine) shall exhibit cracks. The need was evident for a suitable heat treatment to eliminate the apparent sensitization of most lots of the as-received sheet material.

\section{Tests on Annealed and Cold-Rolled Plate}

In an effort to eliminate sensitization of as-received plate, the plate was annealed at $400{ }^{\circ} \mathrm{C}$ for 3 hours and was water-quenched. Fourteen 0.70-in.-o. d. 
TABLE 2. Results of C-Ring Tests on AsReceived, 5083-H321 Sheet Aluminum

\begin{tabular}{|c|c|c|c|c|}
\hline $\begin{array}{c}\text { Sample } \\
\text { Set } \\
\text { Number } \\
\end{array}$ & Identification & $\begin{array}{c}\text { Number of } \\
\text { C-Rings } \\
\text { Tested } \\
\end{array}$ & $\begin{array}{c}\text { Number of } \\
\text { Visual } \\
\text { Failures } \\
\end{array}$ & $\begin{array}{l}\text { Time to } \\
\text { Failure } \\
\text { (days) }\end{array}$ \\
\hline 1 & $\begin{array}{c}\text { Batch A000763 } \\
\text { (1.0-in. sheet) }\end{array}$ & 9 & 3 & $6,6,7$ \\
\hline 2 & $\begin{array}{c}\text { Alcoa-5083-H321 } \\
\text { (1.0-in. sheet) }\end{array}$ & 9 & 4 & $\begin{array}{l}14,14 \\
14,20\end{array}$ \\
\hline 3 & $\begin{array}{c}\text { Alcoa-5083-H321 } \\
\text { (0.75-in. sheet) }\end{array}$ & 9 & 0 & $\cdots$ \\
\hline 4 & $\begin{array}{c}\text { Alcoa-5083-H321 } \\
\text { Batch 1053271-3 } \\
\text { (0.75-in. sheet) }\end{array}$ & 9 & 7 & $\begin{array}{l}4,4,4, \\
4,6,7 \\
8\end{array}$ \\
\hline
\end{tabular}

C-rings were removed from the annealed plate and were subjected to the 30-day alternate immersion SCC test. Results of these tests are shown in Table 3. None of the $14 \mathrm{C}$-rings failed the 30-day test. Thus; sensitization of the as-received plate can be easily removed.

To investigate the SCC effects of cold-working to increase material strength, the annealed sheet was cross-rolled at $23^{\circ} \mathrm{C}$ to a $25 \%$ reduction in thickness. Fourteen additional 0.50-in.-0. d. C-rings were fabricated from the rolled sheet and subjected to the alternate immersion 30-day test, the results of which are also listed in Table 3. No cracks were detected for any of the $\mathbf{C}$-rings in this test series. Thus, annealed plate, and annealed and cold-rolled plate are not sensitized and are not subject to stress corrosion cracking.

\section{Tests for Various Experimental \\ Heat Treatments and Forming Parameters}

Various experimental heat treatments and forming parameters were examined next by means of alternate immersion SCC testing. The diagnostic tests are summarized in Tables 4 and 5. Most of these tests consisted of 1 or 2 C-ring samples, which was an insufficient sample population for a valid ASTM test. The results were useful, however, for diagnostic purposes. All detected cracking in Tables 4 and 5 occurred within the first 11 days of the 30-day
TABLE 3. Results of Stress Corrosion Cracking Tests on Annealed Plate and on Annealed and Cold-Rolled Plate

$\begin{gathered}\text { Thermal and } \\ \text { Mechanical History }\end{gathered} \begin{gathered}\text { Number of } \\ \text { C-Rings Tested }\end{gathered}$
$\begin{aligned} & \text { As-received } 5083- \\ & \text { H321 } 0.75 \text { in. plate } \\ & \text { annealed at } 400^{\circ} \mathrm{C} \\ & \text { for } 3 \text { hours and } \\ & \text { water-quenched. }\end{aligned}$
$\begin{aligned} & \text { As above plus cross- } \\ & \text { solling at } 23^{\circ} \mathrm{C} \text { to a }\end{aligned}$
thickness of 0.50 in.

test; most of the cracks were detected in the first 4-7 days.

Table 4 lists SCC test results on 5083 aluminum samples that were not cross-rolled. Of the 18 C-rings tested, 8 failed the 30-day alternate immersion SCC test. Although the sample populations were small, it can be concluded that the annealed material is not sensitized, and that all of the asformed, and the as-formed and stabilized press parts are sensitized. It can also be concluded that longer stabilization times are detrimental from a sensitization, and hence, an SCC point of view.

Table 5 lists SCC test results on cross-rolled 5083 aluminum samples. Here again the sample populations are too small to draw definite conclusions, but it appears the material is sensitized, and hence, subject to SCC.

\section{Acceptance Tests for Two Fabrication Procedures}

Alternate immersion SCC acceptance tests on two similar fabrication procedures were conducted. The process acceptance tests were performed on 5 pressformed parts ( $16 \mathrm{C}$-rings per part) for a total of 80 C-rings (0.5-in. 0. d.). Forty of the C-rings were from parts formed by the following thermomechanical process:
1. Solutionize forming blanks cut from as-received 5083-H32.1 sheet for 3 hours at $400^{\circ} \mathrm{C}$ and water-quench. 
TABLE 4. Results of Stress Corrosion Cracking Tests on 5083 Aluminum (Not Cross-Rolled)

\begin{tabular}{|c|c|c|c|}
\hline $\begin{array}{l}\text { Thermal and } \\
\text { Mechanical History }\end{array}$ & C-Rings Tested & Visual Failures & $\begin{array}{l}\text { failure } \\
\text { (days) } \\
\end{array}$ \\
\hline 1. Annealed $3 \mathrm{hr}$ at $400^{\circ} \mathrm{C}$, W.Q. & 2 & 0 & -- \\
\hline $\begin{array}{l}\text { 2. Annealed } 3 \mathrm{hr} \text { at } 400^{\circ} \mathrm{C} \text {, W.Q., } \\
\text { press formed at } 23^{\circ} \mathrm{C}\end{array}$ & 2 & 1 & 4 \\
\hline $\begin{array}{l}\text { 3. Annealed } 3 \mathrm{hr} \text { at } 400^{\circ} \mathrm{C} \text {, W.Q., } \\
\text { press formed at } 23^{\circ} \mathrm{C} \text { and } 1 \mathrm{hr} \text { at } \\
175^{\circ} \mathrm{C}\end{array}$ & 2 & 1 & 11 \\
\hline 4. Same as No. 3 plus $0.5 \mathrm{hr}$ at $150^{\circ} \mathrm{C}$ & 1 & 1 & 11 \\
\hline 5. Same as No. 3 plus $1.0 \mathrm{hr}$ at $150^{\circ} \mathrm{C}$ & 2 & $\mathbf{0}$ & -- \\
\hline 6. Same as No. 3 plus $1.5 \mathrm{hr}$ at $150^{\circ} \mathrm{C}$ & 2 & $\mathbf{0}$ & -- \\
\hline 7. Same as No. 3 plus $2.0 \mathrm{hr}$ at $150^{\circ} \mathrm{C}$ & 2 & 1 & 5 \\
\hline 8. Same as No. 3 plus $2.5 \mathrm{hr}$ at $150^{\circ} \mathrm{C}$ & 2 & 1 & 4 \\
\hline 9. Same as No. 3 plus $3.0 \mathrm{hr}$ at $150^{\circ} \mathrm{C}$ & 2 & 2 & 4,11 \\
\hline 10. Same as No. 3 plus $3.5 \mathrm{hr}$ at $150^{\circ} \mathrm{C}$ & 1 & 1 & 4 \\
\hline
\end{tabular}

W.Q. - water quench

TABLE 5. Results of Stress Corrosion Cracking Tests on 5083 Aluminum (Cross-Rolled)

\begin{tabular}{|c|c|c|c|}
\hline $\begin{array}{l}\text { Thermal and } \\
\text { Mechanical History }\end{array}$ & C-Rings Tested & Visual Failures & $\begin{array}{l}\text { Failure } \\
\text { (days) } \\
\end{array}$ \\
\hline $\begin{array}{l}\text { Annealed } 400^{\circ} \mathrm{C} \text { for } 3 \mathrm{hr}, \mathrm{W} . \mathrm{Q} . \text {. }^{*} \\
\text { cross-rolled } 25 \% \text { at } 23^{\circ} \mathrm{C}, 1 \mathrm{hr} \text { at } \\
175^{\circ} \mathrm{C} \text {, press formed, no } \\
\text { stabilization }\end{array}$ & 2 & 0 & -- \\
\hline $\begin{array}{l}\text { Annealed } 400^{\circ} \mathrm{C} \text { for } 3 \mathrm{hr}, \text { W.Q., } \\
\text { cross-rolled } 25 \% \text { at } 23^{\circ} \mathrm{C}, 1 \mathrm{hr} \text { at } \\
175^{\circ} \mathrm{C} \text {, press formed, stabilization } \\
\text { treatment of } 1 \mathrm{hr} \text { at } 150^{\circ} \mathrm{C}\end{array}$ & 6 & 4 & $4,5,8,11$ \\
\hline $\begin{array}{l}\text { As-received plate (no anneal), press } \\
\text { formed at } 230^{\circ} \mathrm{C}\end{array}$ & 2 & 1 & 4 \\
\hline
\end{tabular}


TABLE 6. Results of Stress Corrosion Cracking Acceptance Tests for Parts Formed at $175^{\circ} \mathrm{C}$ With and Without a Subsequent Stabilization Treatment

\begin{tabular}{|c|c|c|c|c|}
\hline $\begin{array}{c}\text { Sample } \\
\text { Identification } \\
\end{array}$ & $\begin{array}{l}\text { Stabilization } \\
\text { Treatment }\end{array}$ & $\begin{array}{l}\text { C-Rings } \\
\text { Tested } \\
\end{array}$ & $\begin{array}{c}\text { Visual } \\
\text { Failures }\end{array}$ & $\begin{array}{c}\begin{array}{c}\text { Time to Failure } \\
\text { (days) }\end{array} \\
\end{array}$ \\
\hline $1-1$ & None & 8 & 8 & $3,3,3,3,3,3,3,3$ \\
\hline $4 A-1$ & None & 8 & 6 & $3,4,5,6,6,7$ \\
\hline 5E-1 & None & 8 & 7 & $3,4,4,4,5,6,7$ \\
\hline GE-1 & None & 8 & 7 & $3,3,4,4,5,5,6$ \\
\hline $7 A-1$ & None & 8 & 6 & $4,5,5,5,5,6$ \\
\hline \multicolumn{2}{|c|}{$\begin{array}{l}\text { SUBTOTAL } \\
\text { AVERAGE }\end{array}$} & 40 & 34 & 4.3 days \\
\hline $1-2$ & $1 \mathrm{hr} 150^{\circ} \mathrm{C}$ & 8 & 4 & $4,4,5,7$ \\
\hline $4 A-2$ & $1 \mathrm{hr} 150^{\circ} \mathrm{C}$ & 8 & 7 & $4,4,4,4,4,5,7$ \\
\hline $5 \mathrm{E}-2$ & $1 \mathrm{hr} 150^{\circ} \mathrm{C}$ & 8 & 8 & $3,3,5,5,5,6,6,7$ \\
\hline GE-2. & $1 \mathrm{hr} 150^{\circ} \mathrm{C}$ & 8 & 7 & $4,4,4,4,4,5,6$ \\
\hline $7 \mathrm{~A}-2^{\circ}$ & $1 \mathrm{hr} 150^{\circ} \mathrm{C}$ & 8 & 5 & $4,4,4,5,6$ \\
\hline \multicolumn{2}{|c|}{$\begin{array}{l}\text { SUBTOTAL } \\
\text { AVERAGE }\end{array}$} & 40 & 31 & 4.7 days \\
\hline \multicolumn{2}{|c|}{$\begin{array}{l}\text { TOTAL } \\
\text { AVERAGE }\end{array}$} & 80 & 65 & 4.5 days \\
\hline
\end{tabular}

2. Cross-roll solutionized forming blanks to $20-25 \%$ reduction in thickness at $23{ }^{\circ} \mathrm{C}$.

3. Press-form after 1 hour in oil at $175^{\circ} \mathrm{C}$, then water-quench.

4. Stabilize 1 hour in air at $150^{\circ} \mathrm{C}$ and waterquench.

The remaining $40 \mathrm{C}$-rings were treated identically except no stabilization treatment at $150^{\circ} \mathrm{C}$ was performed. Physically this was done by cutting the press-formed part in half after Step 3, and giving half of each part a stabilization treatment.

Results of the process acceptance tests are listed in Table 6. Sixty-five of the $80 \mathrm{C}$-rings showed cracks during the first 7 days of the 30-day test exposure. The $\mathrm{C}$-rings that did not crack during the first 7 days lasted the full $\mathbf{3 0}$ days without visible crack formation. Statistically there was no SCC difference between material that had received a stabilization treatment and that which had not (34 failures out of 40 for no stabilization and 31 out of $\mathbf{4 0}$ for stabilized material). The average time to observe failure was 4.5 days. Thus, one must conclude that parts formed at $175^{\circ} \mathrm{C}$ with or without a subsequent stabilization treatment are sensitized and will stress corrosion crack in the test environment studied.

Acceptance Tests for an

Alternate Fabrication Procedure

An alternate fabrication process was developed that hopefully would not sensitize the material and hence would not crack in the SCC test. The alternate forming procedure was as follows:

1. Solutionize forming blanks cut from as-received 5083-H321 sheet 2 hours at $260^{\circ} \mathrm{C}$ in air and water-quench.

2. Cross-roll solutionized forming blanks to $20-25 \%$ reduction in thickness at $23{ }^{\circ} \mathrm{C}$.

3. Flash-heat to $230^{\circ} \mathrm{C}$ in oil for 5 minutes, (normally a maximum of 15 minutes), pressform, and water-quench.

4. No stabilization treatment. 
TABLE 7. Results of Stress Corrosion Cracking

Tests for Parts Formed by Flash-Heating to $230^{\circ} \mathrm{C}$

\begin{tabular}{cccccc}
$\begin{array}{c}\text { Sample } \\
\text { Identification }\end{array}$ & $\begin{array}{c}\text { Stabilization } \\
\text { Treatment }\end{array}$ & $\begin{array}{c}\text { C-Rings } \\
\text { Tested }\end{array}$ & $\begin{array}{c}\text { Visual } \\
\text { Failures }\end{array}$ & $\begin{array}{c}\text { Time-To } \\
\text { Failure } \\
\text { (days) }\end{array}$ \\
\cline { 1 - 1 } Series 1 & None & 16 & 0 & No failures \\
Series 2 & None & 56 & 7 & <11 days
\end{tabular}

Nine parts were formed by this method. Each part was cut in half and $8 \mathrm{C}$-rings (0.5-in. 0 . d.) were obtained from one half of each part, which yielded a total of $72 \mathrm{C}$-rings for testing. The other half of each pressed part was saved for historical purposes.

Results of the alternate immersion tests are listed in Table 7. Seven of the 72 C-rings tested showed evidence of cracking after $\mathbf{3 0}$ days of test exposure. Thus, one can conclude that parts formed by flashheating to $230^{\circ} \mathrm{C}$ and without a subsequent stabilization treatment are not sensitized and will not crack from stress corrosion in the test environment studied.

\section{SUMMARY}

Service reliability of the alternate immersion test apparatus has been proven to be trouble free after nearly two years of almost continuous testing. Reproducibility of the controlled test environment to produce stress corrosion cracks in susceptible (sensitized) material shows the method is suitable for process prove-in SCC tests.

The results of testing 234 C-rings are (a) As-received 5083-H321 plate is often sensitized and will normally not pass the SCC test; (b) Sensitization of as-received plate can be removed by an annealing treatment; (c) Annealed and cold-rolled plate (reduced 20-25\%) is not subject to SCC; (d) Parts press-formed in the range of $65-205^{\circ} \mathrm{C}$ with or without a subsequent stabilization treatment are sensitized and will stress corrosion crack; and (e) Parts press-formed by the specified $230^{\circ} \mathrm{C}$ operation are not sensitized and will not crack from stress corrosion.

\section{REFERENCES}

1. H. L. Craig, Jr. and H. B. Romans. "A Rapid Stress Corrosion Test for AluminumMagnesium Alloys." ASTM STP 425. p. 51. American Society for Testing and Materials. 1967.

2. E. H. Dix, Jr., W. A. Anderson, and M. B. Shumaker. "Influence of Service Temperature on the Resistance of Wrought Aluminum Alloys to Corrosion." Corrosion, Vol. 15, pp. 558-628. 1959.

3. "Standard Recommended Practice for Alternate Immersion Stress Corrosion Cracking in 3.5\% Sodium Chloride Solution." Annual Book of ASTM Standards, G44-75. American Society for Testing and Materials. 1975.

4. Industrial Hydraulic Manual. 935100A, Sperry Rand Corporation. pp. 4-9, 1970.

5. H. Rosenthal and H. R. Pritchard. "A Quantitative Stress Corrosion Test for Al-Zn-Mg Alloy Plate." ASTM STP 425, p. 165. American Society for Testing and Materials. 1967.

6. "Metallographic Structures and Phase Diagrams." Metals Handbook, Vol. 8, p. 261. American Society for Metals. Metals Park, Ohio. 1973. 